\title{
Reactivity between carbon cathode materials and electrolyte based on industrial and
}

\author{
laboratory data \\ L Chauke $^{\mathrm{a}^{*}}$ and AM Garbers-Craig ${ }^{\mathrm{b} \dagger}$
}

a Department of Materials Science and Metallurgical Engineering, University of Pretoria, Pretoria, 0002, South Africa.

b Department of Materials Science and Metallurgical Engineering, University of Pretoria, Pretoria, 0002, South Africa

\begin{abstract}
Interaction between electrolyte and carbon cathodes during the electrolytic production of aluminium decreases cell life. This paper describes the interaction between carbon cathode materials and electrolyte, based on industrial and laboratory data. It also reports on the degree of expansion of semi-graphitic and graphitised materials when exposed to a sodium rich environment. Phase relations in the slow cooled bath electrolyte, spent industrial cathodes and laboratory scale cathode samples were similar: all contained $\mathrm{Na}_{3} \mathrm{AlF}_{6}, \mathrm{NaF}$, $\mathrm{CaF}_{2}$ and $\mathrm{NaAl}_{11} \mathrm{O}_{17} . \mathrm{Al}_{4} \mathrm{C}_{3}, \mathrm{AlN}$ and $\mathrm{NaCN}$ were only detected in the spent industrial cathodes. The inability to locate $\mathrm{Al}_{4} \mathrm{C}_{3}$ in the laboratory scale samples could be due to very low concentrations of $\mathrm{Al}_{4} \mathrm{C}_{3}$ which could not be detected by XRD, or to the limited direct contact between the produced aluminium and carbon material. X-ray diffraction analysis confirmed that sodium intercalation into graphite did not take place. Wear of the examined carbon cathodes proceeded due to penetration of electrolyte and sodium into the cathode,
\end{abstract}

\footnotetext{
* Currently with Materials Science and Manufacturing, CSIR, Pretoria, 0001, South Africa.

${ }^{\dagger}$ Corresponding author. Fax: +2712362 5304. E-mail address: Andrie.GarbersCraig@up.ac.za (A.M. Garbers-Craig)
} 
followed by reactions with carbon and $\mathrm{N}_{2}$ whereby $\mathrm{AIN}$ and $\mathrm{NaCN}$ formed. Once electrolysis started the carbon cathodes expanded rapidly, but slowed down after approximately an hour. Sodium expansion decreased with degree of graphitisation of the carbon cathode material.

\section{Introduction}

During the electrolytic production of aluminium in the Hall-Heroult cell, electrolyte and sodium penetrate and react with the carbon cathode material $[1,2,3]$. The cathode subsequently goes through significant changes in its chemical, physical and mechanical properties during operation, which cause degradation of the cathode and contribute to premature cell shutdowns. Penetration of bath constituents and sodium into the carbon cathode are highly dependent on the degree of graphitisation of the cathode as well as porosity, pore size distribution and granulometries, as micro pores provide penetration paths and capillary forces for the bath to penetrate the carbon cathode $[4,5]$.

The interaction between the electrolyte and different types of carbon cathode blocks has been studied extensively. These studies have included the post mortem analyses of carbon cathodes from spent pot linings [6-11], and the evaluation of different types of carbon cathode materials in laboratory scale electrolysis $[5,12,13]$ and Rapoport-Samoilenko or sodium-swelling experiments $[6,7,14]$. Crystalline phases that have been reported to be present in slow cooled industrial and laboratory cathode samples include $\mathrm{Na}_{3} \mathrm{AlF}_{6}, \mathrm{NaF}$, $\mathrm{Na}_{5} \mathrm{Al}_{3} \mathrm{~F}_{14}, \mathrm{Na}_{2} \mathrm{O} .11 \mathrm{Al}_{2} \mathrm{O}_{3}, \mathrm{NaAlO}_{2}, \alpha-\mathrm{Al}_{2} \mathrm{O}_{3}, \mathrm{Al}_{4} \mathrm{C}_{3}, \mathrm{NaCN}, \mathrm{AIN}, \mathrm{Na}_{2} \mathrm{CO}_{3}$ and $\mathrm{NaCaAlF}_{6}$ $[3,15,16]$. Proposed mechanisms explaining observed wear in carbon cathodes include sodium intercalation between graphite layers and chemical reactions between gaseous species, aluminium, electrolyte, sodium and carbon $[1,17]$. It is reported that reactions 
between carbon and gaseous species involve reactions with $\mathrm{O}_{2}$ and $\mathrm{N}_{2}$ in the air, anode gases and decomposed carbonates [1]. Zolochevsky et al. claimed that sodium can form from reaction between aluminium and electrolyte according to reaction 1 , or electrochemically according to reaction $2[6]$ :

$$
\begin{aligned}
& \mathrm{Al}(\mathrm{l})+3 \mathrm{NaF}(\text { in cryolite })=3 \mathrm{Na}(\text { in } \mathrm{Al})+\mathrm{AlF}_{3}(\text { in cryolite }) \\
& \mathrm{Na}^{+}+1 \mathrm{e}^{-}=\mathrm{Na}(\text { in } \mathrm{C})
\end{aligned}
$$

The mechanisms whereby sodium penetrate and diffuse into the carbon lining are still not fully understood. The following penetration mechanisms have been reported $[3,17]$ :

i. An interfacial solid state diffusion process via mass transfer, whereby sodium penetrate inside carbon under a chemical potential gradient;

ii. The direct reduction of sodium ions at the cathode interface and its direct insertion in carbon as shown in equation (2);

iii. The absorption of sodium from the vapour phase into the porosity of the carbon.

Hop et al. studied the thermodynamics of reactions and compounds that can form during the aluminium electrolysis process at $950^{\circ} \mathrm{C}$ [18]. They found that if only $\mathrm{Na}, \mathrm{C}$ and $\mathrm{N}_{2}$ are present $\mathrm{NaCN}$ will form, and that $\mathrm{NaCN}$ becomes unstable in the presence of $\mathrm{Na}_{3} \mathrm{AlF}_{6}$, and reacts to form AlN (reactions 3 and 4):

$$
\begin{aligned}
& 3 / 2 \mathrm{~N}_{2}(\mathrm{~g})+3 \mathrm{C}(\mathrm{s})+3 \mathrm{Na}(\text { in } \mathrm{C})=3 \mathrm{NaCN}(\mathrm{l}) \\
& 3 / 2 \mathrm{Na}_{3} \mathrm{AlF}_{6}(\mathrm{l})+3 / 2 \mathrm{NaCN}(\mathrm{l})+3 \mathrm{Na}(\text { in } \mathrm{C})=3 / 2 \mathrm{AlN}(\mathrm{s})+9 \mathrm{NaF}(\mathrm{l})+3 / 2 \mathrm{C}(\mathrm{s})
\end{aligned}
$$

They also reported that $\mathrm{Na}_{3} \mathrm{AlF}_{6}$ can react with $\mathrm{N}_{2}$ to form $\mathrm{AlN}$ (reaction 5):

$$
\mathrm{Na}_{3} \mathrm{AlF}_{6}(\mathrm{l})+1 / 2 \mathrm{~N}_{2}(\mathrm{~g})+3 \mathrm{Na}(\text { in } \mathrm{C})=\mathrm{AlN}(\mathrm{s})+6 \mathrm{NaF}(\mathrm{l})
$$

Different mechanisms have been proposed for the formation of $\mathrm{Al}_{4} \mathrm{C}_{3}$ and how it affects the wear of carbon cathodes. Thermodynamically the formation of $\mathrm{Al}_{4} \mathrm{C}_{3}$ is favoured at all 
electrolysis temperatures when carbon and liquid aluminium come in direct contact [19], but according to Hop et al. it can also form from $\mathrm{Na}_{3} \mathrm{AlF}_{6}$ in an argon atmosphere (reaction 6) [18]:

$$
\mathrm{Na}_{3} \mathrm{AlF}_{6}(\mathrm{l})+3 \mathrm{Na}(\text { in } \mathrm{C})+3 / 4 \mathrm{C}(\mathrm{s})=1 / 4 \mathrm{Al}_{4} \mathrm{C}_{3}+6 \mathrm{NaF}(\mathrm{l})
$$

Various researchers have reported that $\mathrm{Al}_{4} \mathrm{C}_{3}$ mainly forms on the cathode surface, and only in pores close to the surface of the cathode $[16,19,20,21]$. The aluminium carbide layer can dissolve and be transported away from the surface, thereby allowing new surfaces to react [20]. Sørlie and Øye reported that $\mathrm{Al}_{4} \mathrm{C}_{3}$ is not stable in the presence of anode gas, and converts to $\mathrm{Al}_{2} \mathrm{O}_{3}$ according to the following reaction [22]:

$\mathrm{Al}_{4} \mathrm{C}_{3}($ dissolved in cryolite $)+9 \mathrm{CO}_{2}(\mathrm{~g})=2 \mathrm{Al}_{2} \mathrm{O}_{3}($ dissolved in cryolite $)+12 \mathrm{CO}(\mathrm{g})$

Work by Zhang et al. on microstructures that form in $\mathrm{MgO}-\mathrm{C}$ refractories that contain aluminium as antioxidant, indicated that as gaseous diffusion into the refractory increased the $\mathrm{Al}_{4} \mathrm{C}_{3}$ (which formed between the aluminium antioxidant and carbon present in the refractory) reacted with $\mathrm{N}_{2}$ from the atmosphere to form AlN, or was directly oxidised by $\mathrm{CO}$ to $\mathrm{Al}_{2} \mathrm{O}_{3}$ [23]. A further increase in $\mathrm{CO}$ and $\mathrm{N}_{2}$ contents of the atmosphere lead to the oxidation of $\mathrm{AlN}$ to $\mathrm{Al}_{2} \mathrm{O}_{3}$. $\mathrm{Al}_{4} \mathrm{C}_{3}$ and $\mathrm{AlN}$ were found to co-exist in MgO-C bricks, where AIN whiskers formed on $\mathrm{Al}_{4} \mathrm{C}_{3}$ grain surfaces.

The main aim of this study was to compare the crystalline phases that formed in slow cooled electrolyte from a Hall-Heroult cell with crystalline phases found in two spent pot linings and in two types of cathode materials (semi-graphitic and graphitised) that were reacted in laboratory electrolysis experiments. This was done to get a better understanding of how the cathode lining wears during short reaction times (laboratory scale experiments) as contrasted to wear over extended periods of time (as reflected by the spent lot linings). Specific 
attention was also given to whether sodium intercalation was a main wear mechanism associated with the examined cathode materials. The study further evaluated different carbon cathode grades (semi-graphitic and graphitised) in terms of their degrees of sodium expansion, porosities and pore size distributions when they were exposed to a sodium rich environment.

\section{Experimental}

\subsection{Samples and sample preparation}

Post mortem and virgin carbon cathode samples were received from a South African aluminium smelter. The spent carbon cathode samples (A and B) were each taken from similar positions (bottom block of the cell, $40 \mathrm{~cm}$ from the sidewall) but from different cells (Figure 1). Virgin samples A and B respectively contained 93\% and 97\% graphite. Sample A was removed from the cell after 1644 days in operation, while sample B was removed after 1944 days.

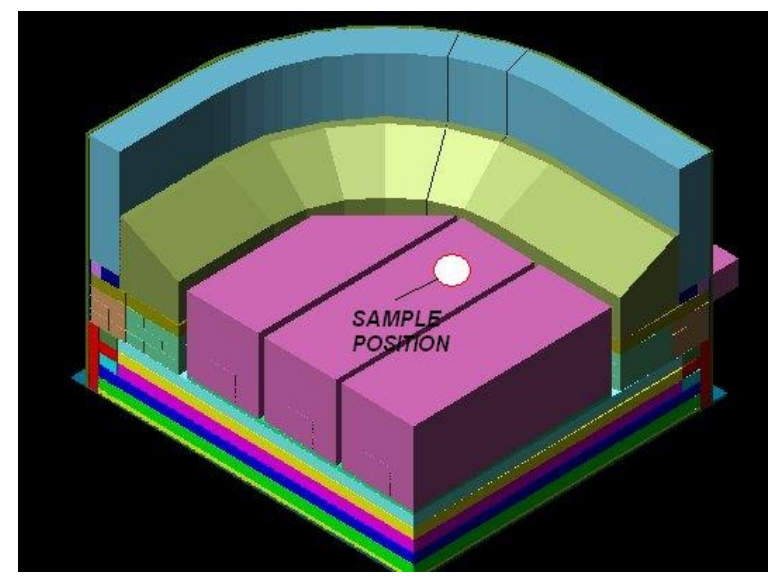

Figure 1. Position from where spent cathode samples were taken 
Each spent cathode sample was cut into five slices, up to $26.81 \mathrm{~mm}$ (sample A) and $33.77 \mathrm{~mm}$ (sample B) below the electrolyte-carbon cathode interface. All of these slices were phase chemically analysed.

A sample of slow cooled solidified electrolyte was also obtained from the smelter for characterisation. The phase composition of this electrolyte was then compared to the phases that were distinguished in the samples of spent cathode, as well as the laboratory scale cathode samples.

Virgin carbon cathodes samples $(50 \mathrm{~mm}$ in diameter, $50 \mathrm{~mm}$ in height $)$ were drilled from commercial semi-graphitic (sample C) and fully graphitised (sample D) carbon blocks. The bulk densities and chemical compositions of these carbon cathodes are given in Table 1.

Table 1: Preparation process, bulk density and chemical analysis of the examined carbon cathode materials

\begin{tabular}{|c|c|c|c|c|c|c|c|c|}
\hline \multirow{2}{*}{$\begin{array}{l}\text { Sample } \\
\text { name }\end{array}$} & \multirow{2}{*}{ Preparation process } & \multirow{4}{*}{$\begin{array}{l}\text { Bulk } \\
\text { Density } \\
\mathrm{g} / \mathrm{cm}^{3}\end{array}$} & \multicolumn{6}{|c|}{ Chemical analysis (mass \%) } \\
\hline & & & & & & & & \\
\hline & & & \multicolumn{6}{|l|}{$\%$} \\
\hline & & & Ash & $\mathrm{C}$ & $\mathrm{S}$ & $\mathrm{N}$ & $\mathrm{H}$ & $\mathrm{O}$ \\
\hline \multirow[t]{3}{*}{$\mathrm{C}$} & Semi-graphitic: & 1.59 & 6.6 & 89.1 & 0.30 & 0.22 & 0.02 & 3.8 \\
\hline & $30 \%$ graphite, baked to & & & & & & & \\
\hline & $1000-1200^{\circ} \mathrm{C}$ & & & & & & & \\
\hline \multirow[t]{6}{*}{$\mathrm{D}$} & Graphitised block: & 1.7 & 1.6 & 97.8 & 0.13 & 0.47 & 0.14 & 0.13 \\
\hline & Whole block (aggregate and & & & & & & & \\
\hline & binder) consisting of & & & & & & & \\
\hline & graphitisable materials, & & & & & & & \\
\hline & which has been heat treated & & & & & & & \\
\hline & at $3000^{\circ} \mathrm{C}$ & & & & & & & \\
\hline
\end{tabular}




\subsection{Experimental procedures}

\subsubsection{Laboratory electrolysis experiments}

The virgin samples were electrolysed in a laboratory scale electrolysis cell that was constructed to simulate the behaviour and conditions of the Hall-Heroult cell. The experimental procedure was based on the Brilloit et al. experimental approach [21], but with minor modifications [24]. The experiments were performed under $\mathrm{N}_{2}$ for respectively 1 hour 30 minutes and 3 hours at $980^{\circ} \mathrm{C}$, using a current density of $0.75 \mathrm{~A} / \mathrm{cm}^{2}$. The electrolyte was prepared from $90 \% \mathrm{Na}_{3} \mathrm{AlF}_{6}, 6 \% \mathrm{Al}_{2} \mathrm{O}_{3}$ and $4 \% \mathrm{CaF}_{2}$ (cryolite ratio of 2.29) giving a total mass of $400 \mathrm{~g}$. The carbon samples were furnace cooled under $\mathrm{N}_{2}$ after each experiment.

\subsubsection{Rapoport or sodium expansion test}

Rapoport sodium expansion experiments were performed on the same carbon grades (samples C and D) as the electrolysis experiments. Samples $(35 \mathrm{~mm}$ in diameter, $90 \mathrm{~mm}$ height) were drilled parallel to the extrusion direction of the block. The sodium expansion tests were performed according to the Council of Scientific and Industrial Research (CSIR) procedure MMP-WP-315 [24]. A bath consisting of $80 \% \mathrm{Na}_{3} \mathrm{AlF}_{6}, 10 \% \mathrm{Al}_{2} \mathrm{O}_{3}$ and $10 \% \mathrm{NaF}$ (with a cryolite ratio of 2.29) was prepared before each experiment. The experiments were performed for respectively 2 and 8 hours at $980^{\circ} \mathrm{C}$. Two sets of measurements were performed for each cathode grade.

\subsection{Analysis techniques}

\subsubsection{X-ray Diffraction Analysis}

$\mathrm{X}$-ray diffraction (XRD) analysis was used to identify and quantify the phases present in the carbon cathode samples. All samples were milled in a WC milling vessel and prepared for XRD analysis using a back loading preparation method. In the semi-quantitative XRD 
analysis, $15 \% \mathrm{Si}$ (Aldrich 99\%) was added to the samples as a standard. The samples were micronized in a McCrone micronising mill under ethanol. A PANalytical X'Pert PRO powder diffractometer, with $\mathrm{X}^{\prime}$ Celerator detector and variable divergence - and receiving slits, using Fe filtered Co- $\mathrm{K}_{\alpha}$ radiation, was used. The phases were identified using X'Pert Highscore plus software.

Sodium intercalation was assessed by examining the position and possible broadening of the $2 \theta=31.00^{\circ}$ graphite peak during the interpretation of the XRD patterns. This was done by looking at the full width at half maximum (FWHM) data of the $2 \theta=31.00^{\circ}$ graphite peak, using the X'Pert Data Viewer software.

\subsubsection{Scanning electron microscopy - energy dispersive spectroscopy}

Scanning electron microscopy - energy dispersive spectroscopy (SEM-EDS) analysis and EDS X-ray mapping were done to confirm the phase compositions, as determined by XRD analysis. This was done by using a JSM 6510 Jeol SEM with an EDS facility.

\subsubsection{Porosity measurements}

The total porosity, apparent porosity and pore size distribution of both virgin carbon cathode materials were determined. The porosity measurements were repeated five times, and average values are reported. For the determination of the pore size distributions two specimens $(5 \mathrm{~mm}$ thick and $25 \mathrm{~mm}$ in diameter) were cut from each carbon grade, mounted in resin, ground and polished using $600 \mu \mathrm{m}-2400 \mu \mathrm{m}$ grinding paper. Thirty arbitrary micrographs of each specimen were taken at the same magnification, after which the images were analysed using the ImageJ software (Java-based image processing programme developed at the National Institute of Health). The image analyses were conducted at different pore sizes. 


\section{Results and discussion}

\subsection{Post mortem analyses of industrial bath and carbon cathode samples}

The solidified electrolyte mostly contained villiaumite $(\mathrm{NaF})$, cryolite $\left(\mathrm{Na}_{3} \mathrm{AlF}_{6}\right)$ and fluorite $\left(\mathrm{CaF}_{2}\right)$, while $\mathrm{Al}_{2} \mathrm{O}_{3}$ and diaoyudaiote $\left(\mathrm{NaAl}_{11} \mathrm{O}_{17}\right.$ or sodium $\beta$-alumina) were present in low concentrations.

The phases that could be distinguished in the electrolyte could be found in cathode samples A and $\mathrm{B}$ (Table 2), except for $\mathrm{Al}_{2} \mathrm{O}_{3}$ which could not be found in cathode sample $\mathrm{B}$. Quantitative XRD analysis indicated that sample A has a higher concentration of $\mathrm{Na}_{3} \mathrm{AlF}_{6}$ than sample $\mathrm{B}(\sim 21 \mathrm{wt} \%$ vs. $\sim 5 \mathrm{wt} \%)$, and also contained $\mathrm{Na}_{5} \mathrm{Al}_{3} \mathrm{~F}_{14}$, which could neither be identified in the solidified electrolyte nor in sample B. Both cathode samples A and B contain trace amounts of the reaction product $\mathrm{AlN}$, while low concentrations of $\mathrm{Al}_{4} \mathrm{C}_{3}$ and trace amounts of $\mathrm{NaCN}$ could only be found in cathode sample $\mathrm{B}$.

The lower concentration of cryolite in sample $\mathrm{B}$ could partly be due to the formation of $\mathrm{Al}_{4} \mathrm{C}_{3}$ according to the reaction 6 . This is also supported by a higher concentration of $\mathrm{NaF}$ in sample B than in sample A ( $\sim 8 \mathrm{wt} \%$ vs. $\sim 2 \mathrm{wt} \%)$. The absence of chiolite in sample B could imply that the bath was depleted of aluminium ions and alumina had to be added, or it can simply indicate that chiolite formed peritectically from cryolite and aluminium fluoride on cooling at $734^{\circ} \mathrm{C}$ [7]. The presence of AlN and $\mathrm{NaCN}$ point to the formation of reaction products within the industrial cathodes, probably through a combination of reactions 3-5. Stereo microscopic analysis confirmed that the microstructure of cathode B was altered to greater depths than cathode A. However, larger open pores could be distinguished in cathode A than in cathode B. 
Table 2: Phases identified in spent industrial cathode samples A and B

\begin{tabular}{|ll|}
\hline \multicolumn{1}{|c|}{ Cathode sample $\mathrm{A}$} & \multicolumn{1}{c|}{ Cathode sample B } \\
\hline $\mathrm{Na}_{3} \mathrm{AlF}_{6}$ (Cryolite) & $\mathrm{Na}_{3} \mathrm{AlF}_{6}$ (Cryolite) \\
\hline $\mathrm{NaF}$ (Villiaumite) & $\mathrm{NaF}$ (Villiaumite) \\
\hline $\mathrm{NaAl}_{11} \mathrm{O}_{17}$ (Diaoyudaoite) & $\mathrm{NaAl}_{11} \mathrm{O}_{17}$ (Diaoyudaoite) \\
\hline $\mathrm{CaF}_{2}$ (Fluorite) & $\mathrm{CaF}_{2}$ (Fluorite) \\
\hline $\mathrm{Al}_{2} \mathrm{O}_{3}$ (Corundum) & n.d. \\
\hline $\mathrm{Na}_{5} \mathrm{Al}_{3} \mathrm{~F}_{14}$ (Chiolite) & $\mathrm{n} . \mathrm{d}$. \\
\hline n.d. & $\mathrm{Al}_{4} \mathrm{C}_{3}$ \\
\hline AlN & $\mathrm{AlN}$ \\
\hline n.d. & $\mathrm{NaCN}$ \\
\hline
\end{tabular}

n.d.: not detected

Full width at half maximum (FWHM) data of the $2 \theta=31.00^{\circ}$ graphite peak confirmed that sodium intercalation did not take place, as no change in peak position, $\mathrm{d}$-spacing or peak broadening could be detected in any of the XRD patterns (Table 3).

Since XRD analysis indicated that intercalation did not take place, it is assumed that sodium diffused along pores in the carbon cathode, reacted with carbon, $\mathrm{N}_{2}$ and cryolite to form $\mathrm{NaCN}$ and AlN according to reactions $3-5$. 
Table 3: Peak position and width of the $2 \theta=31.00^{\circ}$ graphite XRD peak

\begin{tabular}{|c|c|c|c|c|c|}
\hline & \multicolumn{5}{|c|}{ Sample number } \\
\hline & 1 & 2 & 3 & 4 & 5 \\
\hline $\begin{array}{c}\text { Unused Carbon } \\
\text { cathode }\end{array}$ & & & & & \\
\hline Position $(2 \theta)$ & 31.00 & 31.00 & 31.00 & 31.00 & 31.00 \\
\hline d-spacing $(\AA)$ & 3.37 & 3.37 & 3.37 & 3.37 & 3.37 \\
\hline 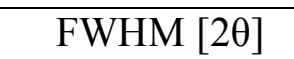 & 0.220 & 0.221 & 0.220 & 0.220 & 0.221 \\
\hline $\begin{array}{c}\text { Carbon cathode } \\
\text { sample A }\end{array}$ & & & & & \\
\hline Position (2 2 ) & 30.99 & 30.99 & 30.99 & 30.99 & 30.99 \\
\hline d-spacing $(\AA)$ & 3.37 & 3.37 & 3.37 & 3.37 & 3.37 \\
\hline 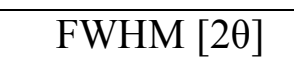 & 0.221 & 0.221 & 0.220 & 0.220 & 0.221 \\
\hline $\begin{array}{c}\text { Carbon cathode } \\
\text { sample B }\end{array}$ & & & & & \\
\hline 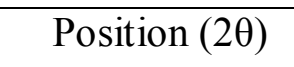 & 31.01 & 31.01 & 31.01 & 31.01 & 31.01 \\
\hline d-spacing $(\AA)$ & 3.37 & 3.37 & 3.37 & 3.37 & 3.37 \\
\hline FWHM [20] & 0.220 & 0.220 & 0.220 & 0.220 & 0.221 \\
\hline
\end{tabular}

\subsection{Laboratory scale electrolysis experiments}

Cryolite was observed in all the laboratory scale carbon cathode samples (Table 4). More cryolite penetrated the $30 \%$ graphite containing cathode than the fully graphitised cathode. The amount of cryolite that penetrated the cathodes increased with increasing time of electrolysis. 
$\mathrm{NaF}$ was not identified in sample $\mathrm{C}\left(30 \%\right.$ graphite) that was reacted for 3 hours. $\mathrm{NaAl}_{11} \mathrm{O}_{17}$ was identified in all the experiments except when sample D (100\% graphitised) was reacted for 1 hour 30 minutes. $\mathrm{CaF}_{2}$ could only be identified in sample $\mathrm{C}$ after 3 hours of reaction, and in sample D after 1 hour 30 minutes. $\mathrm{Na}_{5} \mathrm{Al}_{3} \mathrm{~F}_{14}$ was only identified in sample $\mathrm{D}$ when it was reacted for 3 hours. $\mathrm{NaCN}, \mathrm{AIN}$ and $\mathrm{Al}_{4} \mathrm{C}_{3}$ could not be detected in any of the laboratory scale samples.

$\mathrm{XRD}$ analysis again indicated that intercalation did not take place as the $2 \theta=31.00^{\circ}$ graphite peak did not shift, the d-spacing did not change, and the peak did not broaden or split.

Table 4: Phases identified in the laboratory scale electrolysis samples

\begin{tabular}{|c|c|c|c|}
\hline \multicolumn{2}{|c|}{ Sample C } & \multicolumn{2}{|c|}{ Sample D } \\
\hline 1 hour 30 minutes & 3 hours & 1 hour 30 minutes & 3 hours \\
\hline $\begin{array}{l}\mathrm{Na}_{3} \mathrm{AlF}_{6} \\
\text { (Cryolite) }\end{array}$ & $\begin{array}{l}\mathrm{Na}_{3} \mathrm{AlF}_{6} \\
\text { (Cryolite) }\end{array}$ & $\begin{array}{l}\mathrm{Na}_{3} \mathrm{AlF}_{6} \\
\text { (Cryolite) }\end{array}$ & $\begin{array}{l}\mathrm{Na}_{3} \mathrm{AlF}_{6} \\
\text { (Cryolite) }\end{array}$ \\
\hline $\begin{array}{l}\mathrm{NaF} \\
\text { (Villiaumite) }\end{array}$ & n.d. & $\begin{array}{l}\mathrm{NaF} \\
\text { (Villiaumite) }\end{array}$ & $\begin{array}{l}\mathrm{NaF} \\
\text { (Villiaumite) }\end{array}$ \\
\hline $\begin{array}{l}\mathrm{NaAl}_{11} \mathrm{O}_{17} \\
\text { (Diaoyudaoite) }\end{array}$ & $\begin{array}{l}\mathrm{NaAl}_{11} \mathrm{O}_{17} \\
\text { (Diaoyudaoite) }\end{array}$ & n.d. & $\begin{array}{l}\mathrm{NaAl}_{11} \mathrm{O}_{17} \\
\text { (Diaoyudaoite) }\end{array}$ \\
\hline n.d. & $\mathrm{CaF}_{2}$ (Fluorite) & $\mathrm{CaF}_{2}$ (Fluorite) & n.d. \\
\hline n.d. & n.d. & n.d. & $\begin{array}{l}\mathrm{Na}_{5} \mathrm{Al}_{3} \mathrm{~F}_{14} \\
\text { (Chiolite) }\end{array}$ \\
\hline
\end{tabular}

n.d.: not detected 


\subsection{Rapoport or sodium expansion results}

Once electrolysis started, the cathode materials expanded rapidly, with the less graphitised carbon cathode (sample C, 30\% graphite) being more susceptible to bath penetration than the 100\% graphitised cathode material (sample D) (Figures 2 and 3). Expansion slowed down after approximately one hour. Sample C expanded $0.78 \%$ after 2 hours and $0.80 \%$ after 8 hours of exposure to the sodium rich environment, while the Sample D expanded only $0.27 \%$ after 2 hours and $0.34 \%$ after 8 hours of exposure.

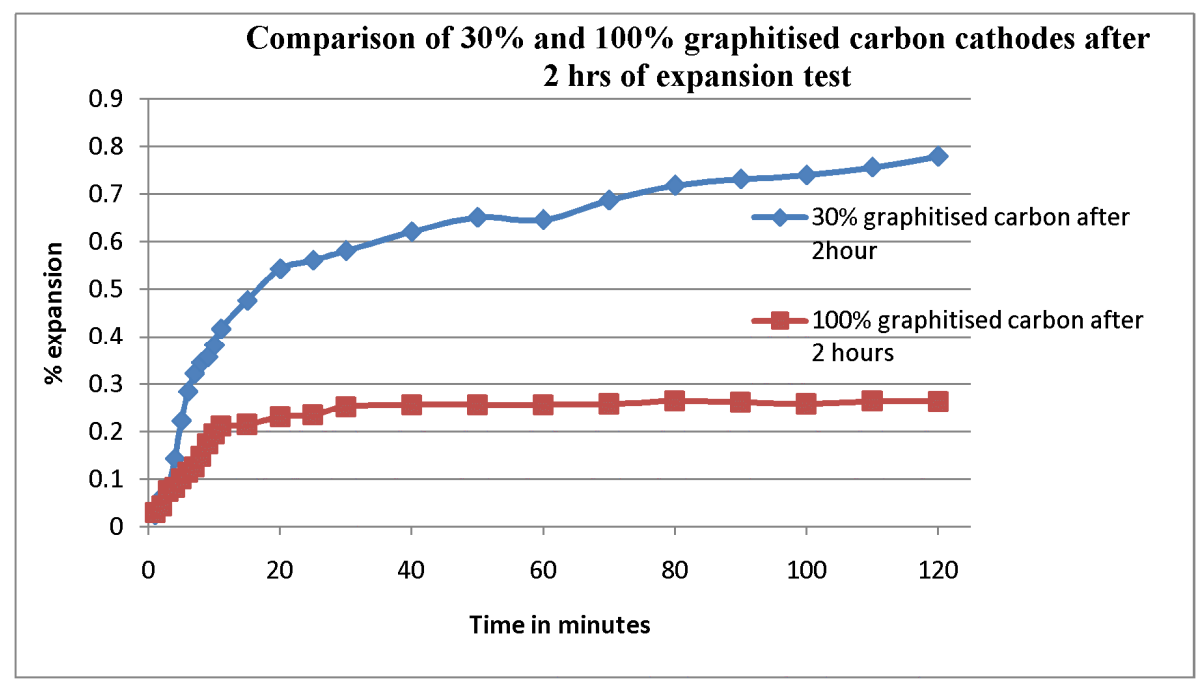

Figure 2: Comparison of degrees of expansion of 30\% and 100\% graphite - containing carbon cathode materials after 2 hours of reaction 


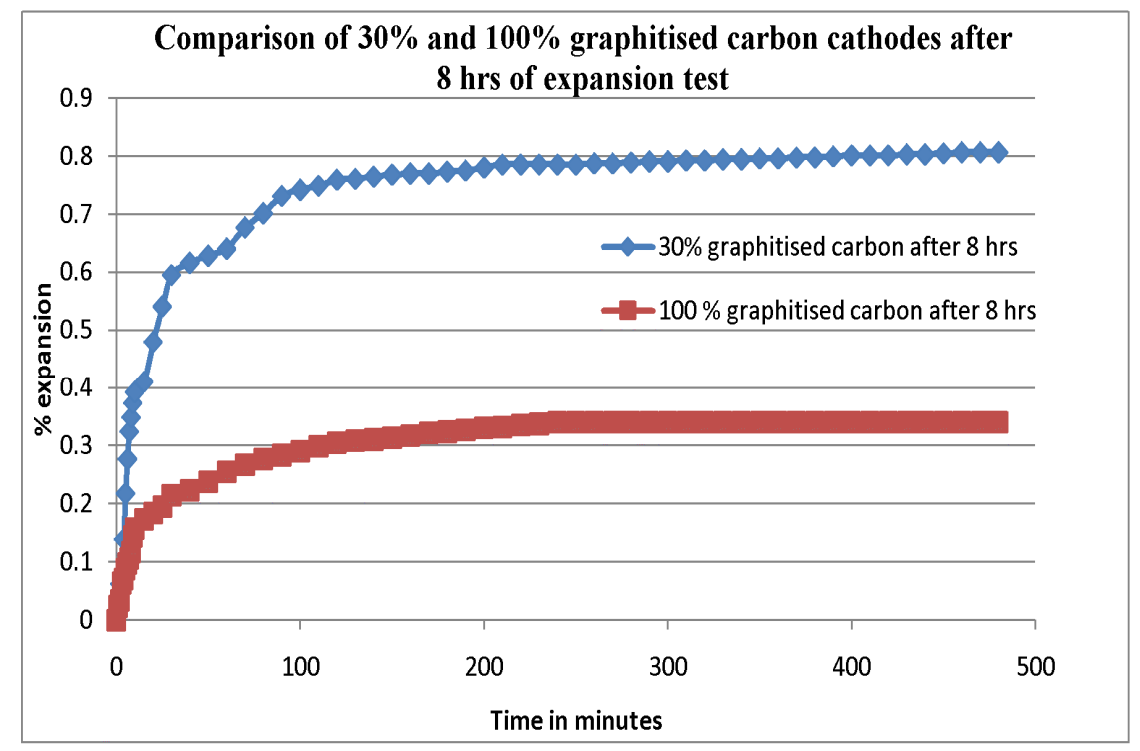

Figure 3: Comparison of degrees of expansion of $30 \%$ and $100 \%$ graphite - containing carbon cathode materials after 8 hours of reaction

\subsection{Porosities and pore size distributions}

The fully graphitised and semi-graphitic cathode materials respectively have total porosities of $21 \pm 3 \%$ and $20 \pm 1 \%$, and open porosities of $19 \pm 2 \%$ and $17 \pm 1 \%$.

Image analysis of the pore size distributions of the cathode materials indicated that the $100 \%$ graphitised material mostly contains small pores $(1-5 \mu \mathrm{m})$, while the semi-graphitic carbon material mostly contains pores in the $200-400 \mu \mathrm{m}$ diameter range. This is similar to what is reported in the literature, namely that the more graphitised materials in general have slightly higher porosities, but with smaller pore sizes $[4,25]$. Since the depth of liquid penetration into a capillary increases with pore diameter, it would be expected that the bath melt will penetrate deeper into the semi-graphitic cathode material, as was the case.

\section{Conclusions}

Phase relations in slow cooled electrolyte, spent industrial cathode and laboratory scale cathode samples were found to be very similar: $\mathrm{Na}_{3} \mathrm{AlF}_{6}, \mathrm{NaF}, \mathrm{CaF}_{2}$ and $\mathrm{NaAl}_{11} \mathrm{O}_{17}$ could be 
distinguished in all of these samples. This finding is similar to what has been reported by Lossius and Øye for sixteen industrial carbon cathodes [16] and Tshöpe et al. for three spent pot linings [11]. Chiolite $\left(\mathrm{Na}_{5} \mathrm{Al}_{3} \mathrm{~F}_{14}\right)$ could only be identified in industrial cathode sample A and laboratory sample D that was reacted for 3 hours. The presence of chiolite could imply that the bath was depleted of aluminium ions and alumina had to be added, or it can simply indicate that chiolite formed on cooling from cryolite and aluminium fluoride through a peritectic reaction at $734^{\circ} \mathrm{C}$ [7]. It should invariably be kept in mind however, that during aluminium electrolysis the electrolyte is molten, and does not contain all of these crystalline phases. Cooling rates in the bath electrolyte as well as cathode blocks with penetrated electrolyte will therefore influence the crystalline phases that precipitate, as well as the proportions in which they precipitate.

$\mathrm{Al}_{4} \mathrm{C}_{3}, \mathrm{AlN}$ and $\mathrm{NaCN}$ were only found in the spent industrial cathode samples, and not in the electrolytic bath sample or any of the laboratory scale cathode samples. The spent cathode samples that were subjected to long reaction times therefore contain reaction products, i.e. phases that did not directly originate from the electrolyte but formed through interaction between the electrolyte, sodium, carbon and nitrogen. Laboratory scale samples that were subjected to short reaction times only contained phases that originated from the electrolytic bath. The inability to detect $\mathrm{Al}_{4} \mathrm{C}_{3}$ in the laboratory scale cathode samples could be due to concentrations of $\mathrm{Al}_{4} \mathrm{C}_{3}$ below the XRD detection limit, or due to limited direct contact between the produced aluminium and carbon cathode material which prevented $\mathrm{Al}_{4} \mathrm{C}_{3}$ from forming (laboratory scale electrolysis resulted in the formation of an aluminium button in the graphite crucible, which did not evenly cover the cathode material). The absence of or limited presence of $\mathrm{Al}_{4} \mathrm{C}_{3}$ in post mortem analyses were also reported by other authors: Lossius and Øye reported that $\mathrm{Al}_{4} \mathrm{C}_{3}$ could be present at the surface of their examined industrial cathode samples, but not in the porosity [16]. Brisson et al. reported the presence 
of small amounts of $\mathrm{Al}_{4} \mathrm{C}_{3}$ in laboratory scale samples [12], while Vasshaug et al. reported that dissolution of $\mathrm{Al}_{4} \mathrm{C}_{3}$ into the bath was faster than its formation, as no $\mathrm{Al}_{4} \mathrm{C}_{3}$ could be observed on the surface of cathode samples which were used in electrolysis experiments [20]. An important finding from this study was that sodium intercalation into graphite did not take place. It can therefore be concluded that sodium was absorbed into the cathode materials through the porosity of the material. Wear of the examined carbon cathodes thus proceeded through electrolyte and sodium penetration, and the subsequent reaction between these species, the carbon cathode and nitrogen gas. It is however uncertain whether sodium penetrates in liquid form into carbon under a chemical potential gradient, or as sodium vapour into the porosity of the carbon, or in both forms.

During the laboratory scale sodium expansion tests expansion started as soon as the electrolysis process commenced. Expansion was rapid during the early stages of electrolysis, but slowed down after an hour. Sodium expansion decreased with degree of graphitisation of the cathode, similar to what is reported in the literature [2]. Associated with the fully graphitised material are mostly small pores $(1-5 \mu \mathrm{m})$, while the semi-graphitic material contains pores predominantly in the $200-400 \mu \mathrm{m}$ diameter range.

\section{Acknowledgements}

The authors would like to thank the Council for Scientific and Industrial Research, and the Technology and Human Resources for Industry Programme (THRIP) of the NRF for research funding. Special thanks are also due to Dr Sabine Verryn and Ms Wiebke Grote for performing the XRD analyses, Messrs Kalenda Mutombo and Sigqibo Camagu for guidance with the SEM-EDS analyses, Drs Sagren Govender, Hein Moller, Dawie van Vuuren and 
Isobel McDougall, as well as Proffs Johan Markgraaf and Johan de Villiers for fruitful discussions.

\section{References}

1. Xue, J, Liu, Q, Zhu, J, Ou, W. Sodium penetration into carbon-based cathodes during aluminium electrolysis. Light Metals 2006; 651-654.

2. Imris, M, Soucy, G, Fafard, M. Carbon cathode resistance against sodium penetration during aluminium electrolysis - An overview. Acta Met Slov 2005; 11(2):231-243.

3. Brisson, P-Y, Darmstadt, H, Fafard, M, Adnot, A, Servant, G, Soucy, G. X-ray photoelectron spectroscopy study of sodium reaction in carbon cathode blocks of aluminium oxide reduction cell. Carbon 2006; 44:1438-1447.

4. Gao, Y, Xue, J, Zhu, J, Jiao, K, Jiang, G. Characterisation of sodium and fluoride penetration into carbon cathodes by image analysis and SEM-EDS techniques. Light Metals 2011; 1103-1107.

5. Patel, P, Hyland, M, Hiltmann, F. Influence of internal cathode structure on behaviour during electrolysis Part II: Porosity and wear mechanisms in graphitized cathode material. Light Metals 2005; 757-762.

6. Zolochevsky, A, Hop, JG, Foosnaes, T, Øye, HA. Rapoport-Samoilenko test for cathode materials-II swelling with external pressure and effect of creep. Carbon 2005; 43:12221230.

7. Zolochevsky, A, Hop, JG, Servant, G, Foosnaes, T, Øye, HA. Creep and sodium expansion in semigraphitic cathode carbon. Light metals 2003; 595-602.

8. Brisson, PY, Soucy, G, Fafard, M, Dionne, M. The effect of sodium on carbon lining of the aluminium electrolysis cell - A review. Can Met Q 2002; 44(2):265-279. 
9. Brisson, PY, Soucy, G, Fafard, M, Darmstadt, H, Servant, G. Revisiting sodium and bath penetration in the carbon lining of aluminium electrolysis cell, Light Metals 2005; 727-732.

10. Tschöpe, K, Schøning, C, Grande, T. Autopsies of spent pot linings - A revised view. Light Metals 2009; 1085-1090.

11. Tschöpe, K, Schøning, C, Rutlin, J, Grande, T. Chemical degradation of cathode linings in Hall-Heroult cells - An autopsy study of three spent pot linings. Met Trans B 2012; 43B:290-301.

12. Brisson, PY, Fafard, M, Soucy, G. Investigation of electrolyte penetration in three carbon cathode materials for aluminium electrolysis cells. Can Met Q 2006; 45(4):417-426.

13. Xue, J, Ou, W, Zhu, J, Liu, Q. Analysis of sodium and cryolite bath penetration in the cathodes used for aluminum electrolysis. Light Metals 2009; 1177-1181.

14. Zolochevsky, A, Hop, JG, Foosnaes, T, Øye, HA. Rapoport-Samoilenko test for cathode materials-I, experimental results and constitutive modelling. Carbon 2003; 41:497-505.

15. Zoukel, A, Chartrand, P and Soucy, G. Study of aluminium carbide formation in HallHeroult cells, Light Metals 2009; 1123-1128.

16. Lossius, LP, Øye, HA. Melt penetration and chemical reactions in 16 industrial aluminium carbon cathodes. Metall Trans B 2000; 31B:1213-1224.

17. Wang, Zh, Rutlin, J, Grande, T. Sodium diffusion in cathode lining in aluminium electrolysis cells. Light Metals 2010; 841-847.

18. Hop, J, Støre, A, Foosnæs, T, Øye, HA. Chemical and physical changes of cathode carbon by aluminium electrolysis. Trans. Inst. Min. Metall. C; 114:C181-C187.

19. Sørlie, M, Øye, HA. Deterioration of carbon linings in aluminium reduction cells. II. Chemical and physical characterization of cathode carbons. Metall 1984; 38(2):109-115. 
20. Vasshaug, K, Foosnæs, T, Haarberg, GM, Ratvik,AP, Skybakmoen, E. Formation and dissolution of aluminium carbide in cathode blocks. Light Metals 2009; 1111-1116.

21. Brilloit, P, Lossius, LP, Øye, HA. Penetration and chemical reactions in carbon cathodes during aluminum electrolysis: part i. laboratory experiments. Metall Trans B 1993; 24(1):75-89.

22. Sørlie, M, Øye, HA. Evaluation of cathode material properties relevant to the life of Hall-Heroult cells. J Applied Electrochem 1989; 19:580-588.

23. Zhang, S, Marriott, NJ, Lee, WE. Thermochemistry and microstructures of MgO-C refractories containing various antioxidants. J Eur Ceram Soc 2001; 21:1037-1047.

24. Chauke, L. Reactivity of carbon cathode materials and electrolyte based on plant and laboratory data. University of Pretoria, Pretoria, South Africa, MSc thesis, 2012.

25. Patel, P, Hyland, M, Hiltmann, F. Influence of internal cathode structure on behaviour during electrolysis Part III: Wear behaviour in graphitic materials. Light Metals 2006; 633-638. 